\title{
Pulmonary Alveolar Microlithiasis
}

\section{Pulmoner Alveoler Mikrolitiyazis}

İpek Özmen,' Hamza Ogun, ${ }^{1}$ Elif Yıldırım, ${ }^{1}$ Aslıhan Ak, ${ }^{1}$ Haluk C. Çalışır ${ }^{2}$

\begin{abstract}
Pulmonary alveolar microlithiasis (PAM) is a rare lung disease characterized by the deposition of calcium in the alveolar spaces and bilateral diffuse micronodular "sandstorm" radiographic pattern. The current report presents the case of a 48-year-old woman with pulmonary alveolar microlithiasis. The patient presented with exertional dyspnea for the past five years. The physical examination was within normal limits and respiratory sounds were normal. The chest $x$-ray revealed a bilateral diffuse micronodular pattern in the middle and the lower areas of both lungs. On the parenchymal window of thorax computed tomography $(\mathrm{CT})$, bilateral diffuse widespread millimetric calcified nodules that were more prominent in the lower lobes were observed. Whole body bone scintigraphy with technetium $-99 \mathrm{~m}$ revealed bilateral, diffuse, heterogeneous, increased uptake in the pulmonary parenchyma. Regarding the current special radiological findings, further invasive diagnostic examination was not performed, the patient was diagnosed with PAM and continues to be followed-up on without treatment.
\end{abstract}

Key words: Bone scintigraphy, calcification, dyspnea, millimetric nodules, pulmonary alveolar microlithiasis.

\section{Özet}

Pulmoner alveoler mikrolitiyazis (PAM) alveollerde kalsiyum birikmesi ile karakterize nadir görülen bir akciğer hastalığıdır. Her iki akciğerde yaygın simetrik mikronodüler radyolojik patern mevcuttur. Bu yazıda 48 yaşında PAM tanısı alan bayan hasta sunulmuştur. Hasta 5 yıldır eforla gelişen nefes darlığı ile başvurdu. Fizik muayene ve solunum sesleri normaldi. Akciğer grafisinde orta ve alt alanlarda bilateral yaygın mikronodüler patern saptandı. Bilgisayarlı toraks tomografisinde parankim penceresinde bilateral alt loblarda daha belirgin olmak üzere yaygın milimetrik kalsifiye nodüller izlenmekteydi. Teknesyum-99m ile yapılan tüm vücut kemik sintigrafisinde her iki hemitoraksta yumuşak doku alanlarında heterojen tarzda diffüz artmış aktivite tutulumu saptandı. Mevcut radyolojik bulguların uyumlu olması ile ileri girişimsel tetkik yapılmadı, hasta PAM tanısı ile tedavisiz takibe alındı.

Anahtar Sözcükler: Dispne, kalsifikasyon, kemik sintigrafisi, milimetrik nodüller, pulmoner alveoler mikrolitiyazis.

\footnotetext{
'Clinic of Chest Diseases, Süreyyapaşa Chest Disease and Thoracic Surgery Teaching and Research Hospital, İstanbul, Turkey

${ }^{2}$ Clinic of Chest Diseases, Acıbadem University, Atakent Hospital, İstanbul, Turkey

'Süreyyapaşa Göğüs Hastalıkları ve Göğüs Cerrahisi Eğitim ve Araştırma Hastanesi, Göğüs Hastalıkları Kliniği, İstanbul ${ }^{2}$ Acıbadem Üniversitesi, Atakent Hastanesi, Göğüs Hastalıkları Kliniği, İstanbul
}

Submitted (Başvuru tarihi): 02.10.2013 Accepted (Kabul tarihi): 13.12.2013

Correspondence (Iletişim): İpek Özmen, Clinic of Chest Diseases, Süreyyapaşa Chest Disease and Thoracic Surgery Teaching and Research Hospital, İstanbul, Turkey e-mail: ozmenipek@yahoo.com 
Pulmonary alveolar microlithiasis (PAM) is a rare lung disease with unknown etiology and characterized by accumulation of calcium and phosphate crystals in alveoli. The disease was first described by Friedrich in 1856 and then by Harbitz in 1918 and called "pulmonary alveolar microlithiasis" by Puhr in 1933 (1-3).

Radiological findings from the posteroanterior chest $\mathrm{x}$-ray are bilateral diffuse symmetric micronodular patterns resembling a "sandstorm". Most cases have been reported from Turkey, followed by Italy and the United States, respectively. In general, PAM can be discovered in any age of patient, but usually remains asymptomatic until the fourth decade (4).

The current article presents the case of a 48 -year-old woman with shortness of breath, and typical radiological findings for PAM are presented.

\section{CASE}

A 48-year-old female patient presented with exertional dyspnea for the past five years that began to increase over the last three months. There was no history of smoking or environmental exposure. On physical examination, the patient's vital signs were within normal limits, has no cyanosis or clubbing of the fingers, respiratory sounds were natural, and there was no remarkable pathological findings on the other systems. Routine complete blood count and biochemical parameters were also normal.

Radiological evaluation of the chest $\mathrm{x}$-ray revealed bilateral symmetrical micronodular alveolar opacities obscuring cardiac and diaphragmatic shadows (Figure 1). In parenchymal window of the thorax computed tomography $(\mathrm{CT})$, bilateral diffuse widespread millimetric nodules more prominent in the lower lobes were observed (Figure 2).

Arterial blood gases in room air were $\mathrm{PCO}_{2}: 36 \mathrm{mmHg}$, $\mathrm{PO}_{2}$ : $69 \mathrm{mmHg}$; pulmonary function tests were: FEV1: 1.75 L (82\%), FVC: 2.25 L (90\%), FEVI/ FVC: 97\%, and TLCO 93\%. The six minute walking test, the patient walked $390 \mathrm{~m}$ without desaturation.

Sputum smears were negative for acid-fast bacilli, there was no hemoptysis or history of any exposure for pneumoconiosis. Regarding the current radiological findings, PAM was considered; whole body bone scintigraphy with technetium-99m revealed bilateral, diffuse, heterogeneous, increased uptake in the pulmonary parenchyma (Figure 3).

The abdominal ultrasound examination revealed an $18 \mathrm{~mm}$ gallstone. Further invasive diagnostic examination was not performed; the patient continues with follow-up without treatment.

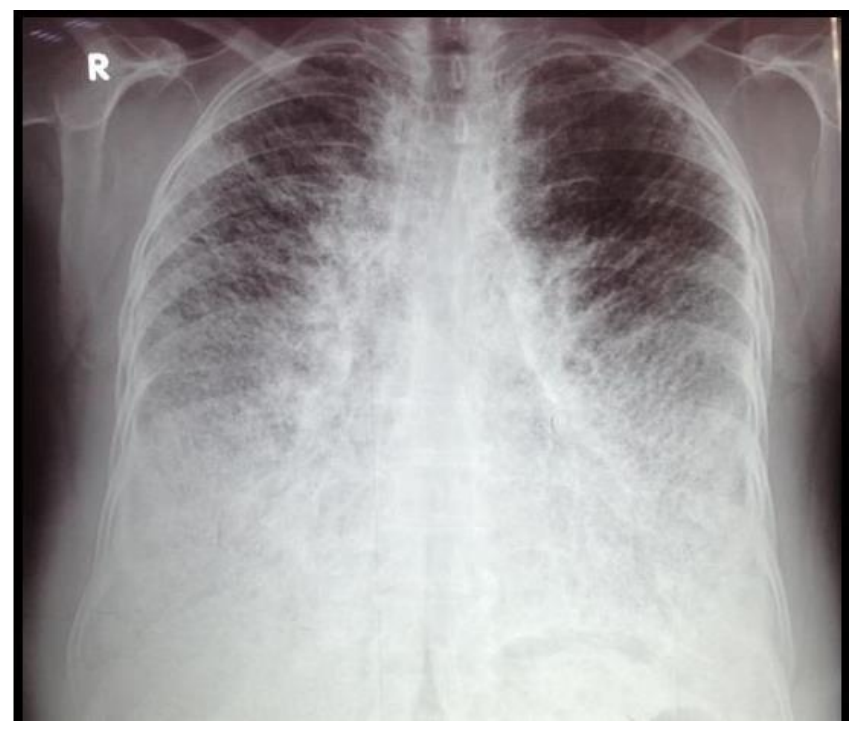

Figure 1: PA chest $x$-ray of the patient showing bilateral symmetrical micronodular alveolar opacities obscuring cardiac and diaphragmatic shadows

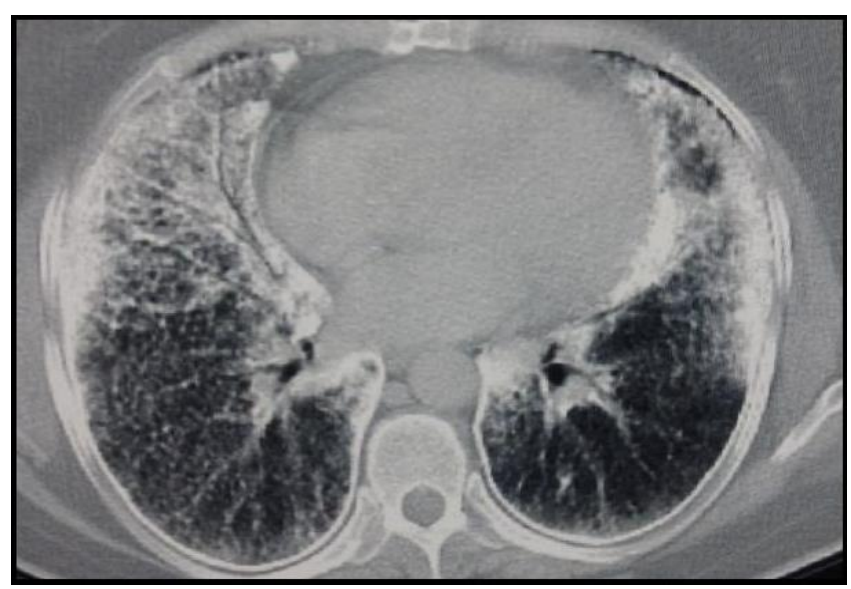

Figure 2: Thorax CT sections of the patient demonstrating bilateral parenchymal micronodular opacities, ground-glass appearance, and mediastinal pleural calcifications. Opacities are predominantly located in the lower lung regions

\section{DISCUSSION}

PAM is a disease that is incompatible with clinical presentation and radiological findings. Despite extensive radiological patterns, symptoms are usually less common. The current case was admitted to a health institution for the first time, although shortness of breath had been present for five years. Shortness of breath on exertion, cough, and chest pain are reported as the most common symptoms in PAM. Sputum, hemoptysis, and when alveolar gas exchange begin to deteriorate, hypoxia, cor pulmonale, and respiratory failure in the later stages of the disease can be encountered $(5,6)$. 


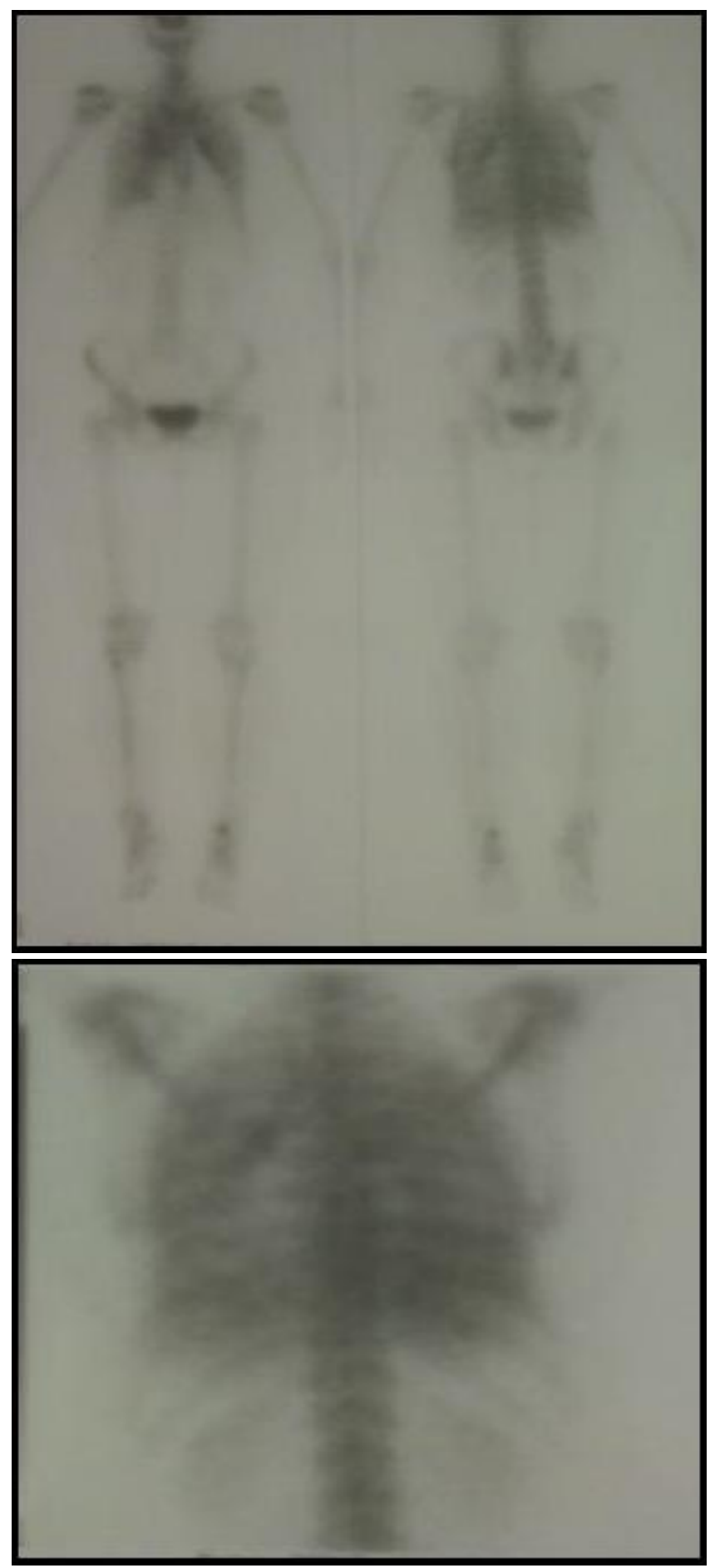

Figure 3: Whole body bone scintigraphy with technetium-99m revealed bilateral, diffuse, heterogeneous, increased uptake in the pulmonary parenchyma

Routine chest $\mathrm{x}$-ray typically shows bilateral ill-defined micronodular patterns, predominantly on the bases (7). PAM is one of the disorders with diagnostic features in radiological images. Chest radiography is especially pathognomonic in familial cases; however, the clinical presentation of the disease is often incompatible with the intensity of the lesions on the chest radiograph. Bone scintigraphy with Tc-99m shows diffuse uptake in both lungs due to the deposition of calcium phosphate in the alveoli (8). Radiological findings are often sufficient for the diagnosis of the disease; however, transbronchial biopsy, bronchoalveolar lavage, or open lung biopsy may sometimes be necessary $(5,8)$. In the light of radiological findings reflecting the typical characteristics of PAM, widespread millimetric nodules on thorax $\mathrm{CT}$, or bone scintigraphy demonstrating the disease-specific findings, invasive procedures was not performed in the current case.

An interstitial pattern can also be present in PAM. High resolution computed tomographic (HRCT) findings of PAM are similar to interstitial lung diseases in varying degrees; micronodules, parenchymal bands, ground glass opacity, subpleural interstitial thickening, interlobular septal thickening, paraseptal emphysema, centrilobular emphysema, bronchiectasis, peribronchovascular interstitial thickening, panacinar emphysema, pleural calcification. Deniz et al. (8) suggests that the degree of parenchymal alterations is also closely related to the degree of pulmonary function loss in patients with PAM.

Mariotta et al. (9) reported an analysis of 576 cases published in literature, and the origins of the cases were mainly reported from Europe (42.7\%) and Asia (40.6\%). The gender predominance around the world is not known, but male predominance was reported from Turkey (4).

Similar radiological findings may be seen in miliary tuberculosis, pneumoconiosis, pulmonary hemosiderosis or sarcoidosis. Pulmonary tuberculosis or sarcoidosis was misdiagnosed in 88 cases of the 576 (9).

The disease can also be sporadic or familial $(9,10)$. As familial transmission of PAM is also reported in nearly one-third of the cases, the current patient's family was also screened with chest $\mathrm{x}$-ray. There was no radiological evidence for PAM in the family.

Macroscopic evaluation of lung quite hard and heavy due to calcific micronodules in PAM. Histopathologically, round calcified structures of $250-750 \mu \mathrm{m}$ diameters is observed (6).

To date, corticosteroids, chelating agents, mechanical ventilation during the end stages of the disease, and bronchoalveolar lavage has been applied for the treatment of PAM, but achieved no significant benefit (11). Recently, lung transplantation for selected cases is promising $(12,13)$.

As a result, PAM is a rare disease with characteristic radiological features and has no specific treatment. Innovations are required for the diagnosis and treatment of this rare disease. 


\section{CONFLICTS OF INTEREST}

None declared.

\section{AUTHOR CONTRIBUTIONS}

Concept - I.Ö., H.O., E.Y., A.A., H.C.Ç.; Planning and Design - I.Ö., H.O., E.Y., A.A., H.C.Ç.; Supervision I.Ö., H.O., E.Y., A.A., H.C.Ç.; Funding - E.Y., A.A., H.O.; Materials - A.A., H.O.; Data Collection and/or Processing - H.O., A.A.; Analysis and/or Interpretation I.Ö., H.C.Ç.; Literature Review - I.Ö., E.Y.; Writing - I.Ö., H.O., H.C.Ç.; Critical Review - H.C.Ç.

\section{YAZAR KATKILARI}

Fikir - I.Ö., H.O., E.Y., A.A., H.C.Ç.; Tasarım ve Dizayn i.Ö., H.O., E.Y., A.A., H.C.Ç.; Denetleme - I.Ö., H.O., E.Y., A.A., H.C.Ç.; Kaynaklar - E.Y., A.A., H.O.; Malzemeler - A.A., H.O.; Veri Toplama ve/veya İşleme - H.O., A.A.; Analiz ve/veya Yorum - I.Ö., H.C.Ç.; Literatür Taraması - I.Ö., E.Y.; Yazıyı Yazan - I.Ö., H.O., H.C.Ç.; Eleştirel İnceleme - H.C.Ç.

\section{REFERENCES}

1. Friedrich N. Corpora amylacea in den Lungen. Arch Pathol Anat 1856; 9:613-8. [CrossRef]

2. Harbitz F. Extensive calcifications of the lungs as distinct disease. Arch Intern Med 1918; 21:139-46. [CrossRef]

3. Puhr L. Microlithiasis alveolarus pulmonum. Virchows Arch 1933; 290:156-60.

4. Ucan ES, Keyf Al, Aydilek R, Yalcin Z, Sebit S, Kudu M, et al. Pulmonary alveolar microlithiasis: review of Turkish reports. Thorax 1993; 48:171-3. [CrossRef]
5. Castellana G, Lamorgese V. Pulmonary alveolar microlithiasis: World cases and review of the literature. Respiration 2003; 70:549-55.

6. Deniz $\bigcirc$. Pulmonary alveolar microlithiasis. Tuberk Toraks $2005 ;$ 53:293-8.

7. Wang BM, Stern EJ, Schmidt RA, Pierson DJ. Diagnosing pulmonary alveolar proteinosis. A review and an update. Chest 1997; $111: 460-6$. [CrossRef]

8. Deniz O, Ors F, Tozkoparan E, Ozcan A, Gumus S, Bozlar $U$, et al. High resolution computed tomographic features of pulmonary alveolar microlithiasis. Eur J Radiol 2005; 55:452-60. [CrossRef]

9. Mariotta S, Ricci A, Papale M, De Clementi F, Sposato B, Guidi $L$, et al. Pulmonary alveolar microlithiasis: report on 576 cases published in the literature. Sarcoidosis Vasc Diffuse Lung Dis 2004; $21: 173-81$.

10. Jankovic S, Pavlov N, Ivkosic A, Erceg I, Glavina-Durdov $M$, Tocili J, et al. Pulmonary alveolar microlithiasis in childhood: clinical and radiological follow-up. Pediatric Pulmonol 2002; 34:384-7. [CrossRef]

11. Göcmen A, Toppare MF, Kiper N, Büyükpamukcu N. Treatment of pulmonary alveolar microlithiasis with a diphosphonate-preliminary results of a case. Respiration $1992 ; 59: 250-2$.

12. Edelman JD, Bavaria J, Kaiser LR, Litzky LA, Palevsky HI, Kotloff RM. Bilateral sequential lung transplantation for pulmonary alveolar microlithiasis. Chest 1997; 112:1140-4. [CrossRef]

13. Shigemura N, Bermudez C, Hattler BG, Johnson B, Crespo $M$, Pilewski J, et al. Lung transplantation for pulmonary alveolar microlithiasis. J Thorac Cardiovasc Surg 2010; 139:,e50-2. [CrossRef] 